\title{
AHP and TOPSIS based selection of aluminium alloy for automobile panels
}

D. SWAPNA, Ch. SRINIVASA RAO, D. Sameer KUMAR, S. RADHIKA

DOI: 10.30464/jmee.2019.3.1.43

Cite this article as:

Swapna D., Srinivasa Rao Ch., Kumar S., Radhika S. AHP and TOPSIS based selection of aluminium alloy for automobile panels. Journal of Mechanical and Energy Engineering, Vol. 3(43), No. 1, 2019, pp. 43-50.

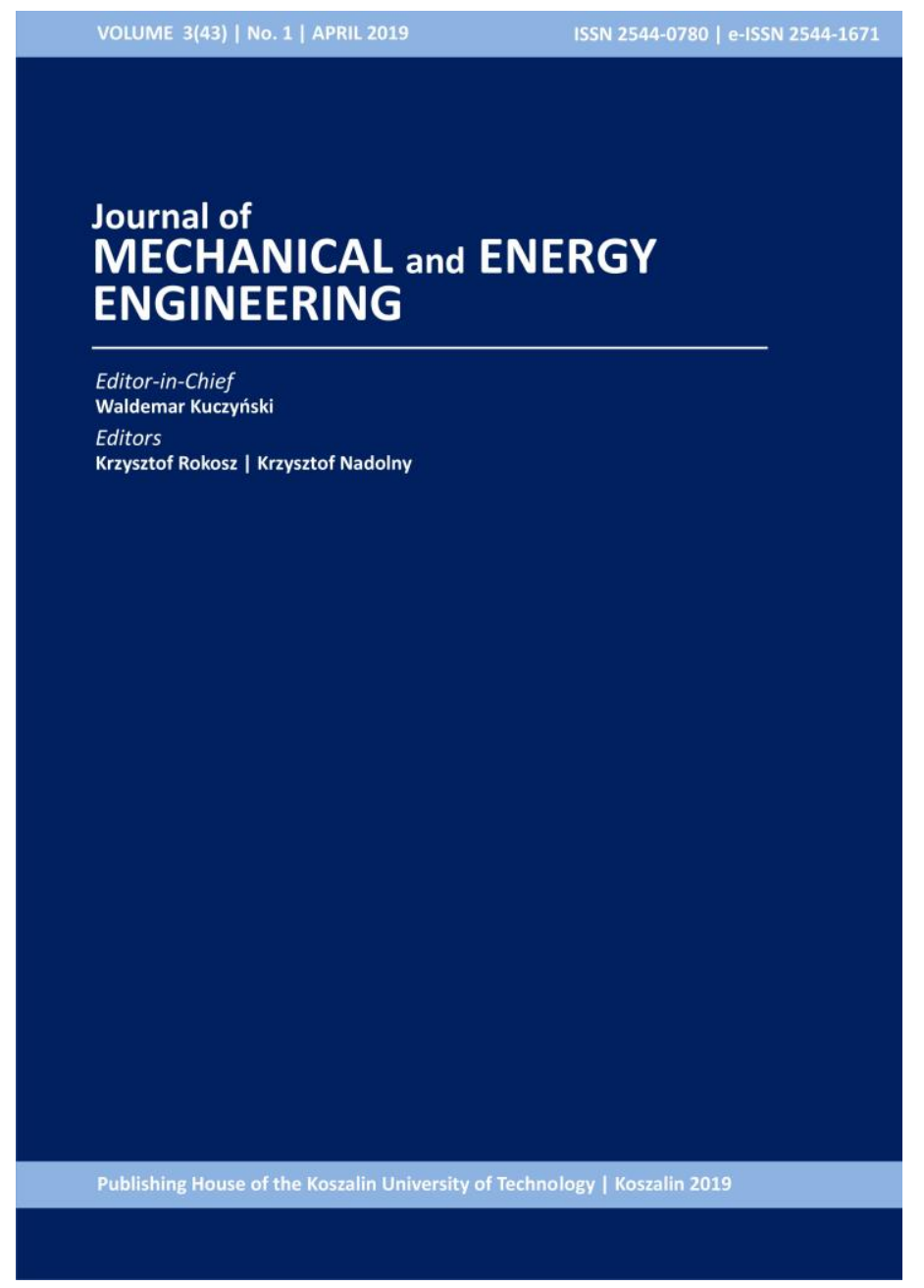

Journal of Mechanical and Energy

Engineering

Website: jmee.tu.koszalin.pl

ISSN (Print): 2544-0780

ISSN (Online): 2544-1671

Volume: 3(43)

Number: 1

Year: 2019

Pages: 43-50

Article Info:

Received 20 February 2019

Accepted 18 March 2019

\section{Open Access}

This article is distributed under the terms of the Creative Commons Attribution 4.0 (CC BY 4.0) International License (http://creativecommons.org/licenses/by/4.0/), which permits unrestricted use, distribution, and reproduction in any medium, provided you give appropriate credit to the original author(s) and the source, provide a link to the Creative Commons license, and indicate if changes were made. 


\title{
AHP AND TOPSIS BASED SELECTION OF ALUMINIUM ALLOY FOR AUTOMOBILE PANELS
}

\author{
D. SWAPNA ${ }^{1 *}$, Ch. SRINIVASA RAO ${ }^{2}$, D. Sameer KUMAR1 S. RADHIKA ${ }^{1}$ \\ ${ }^{1}$ Department of Mechanical Engineering, R.V.R. \& J.C College of Engineering, Guntur, India, \\ e-mail: dswapna32@gmail.com \\ ${ }^{2}$ Department of Mechanical Engineering, College of Engineering, Andhra University, Visakhapatnam, India
}

(Received 20 February 2019, Accepted 18 March 2019)

\begin{abstract}
Automotive industry is a very attractive area for young researchers to do continuous research and also it can be considered as an important thrust area as it is directly related to passenger safety. New developments in automotive sector can be seen in many domains like material selection, design, manufacturing etc. Since wrong selection directly leads to product failure, among these, the proper selection of a particular material can be treat as utmost priority. Hence, the present work discusses a methodology to select the best aluminium alloy for automobile panels among various alternates serving the same purpose. Analytical Hierarchy Process (AHP) and Technique for Order of Preference by Similarity to Ideal Solution (TOPSIS) methods with entropy weighting criteria are implemented for finding the best material and the results are discussed.
\end{abstract}

Keywords:Material selection, MADM methods, AHP, TOPSIS, aluminium alloys

\section{INTRODUCTION}

Automotive designers are seeking for lightweight materials with greater strengths. In modern vehicles, many automotive parts made of steel are being replaced with aluminium for weight reduction which enhances the fuel economy and consequently reduces the $\mathrm{CO}_{2}$ emissions [1]. Excellent properties of aluminium alloy such as high strength, corrosion resistance and weldability drives young researchers to forward the research with aluminium as an alternate to steel.

Further, keeping weight reduction as main objective for most of the auto motor components previously generated by casting and extrusion are replaced by sheets parts as shown in Fig. 1 .

The shape generated by steel sheet cannot be developed by aluminum alloys without failures because of its design shape limits and lower degree of freedom in forming. General failures such as wrinkling in steel are modified by improving the blank holder force which cannot be applied for aluminum alloys as it creates cracks leading to damage of components. Compared to steel, aluminum has $1 / 3$ modulus of elasticity, low anisotropy values which tend to extensive local deformation. So the design of automotive panels with Aluminum alloys is always a challenging mission for the designers.

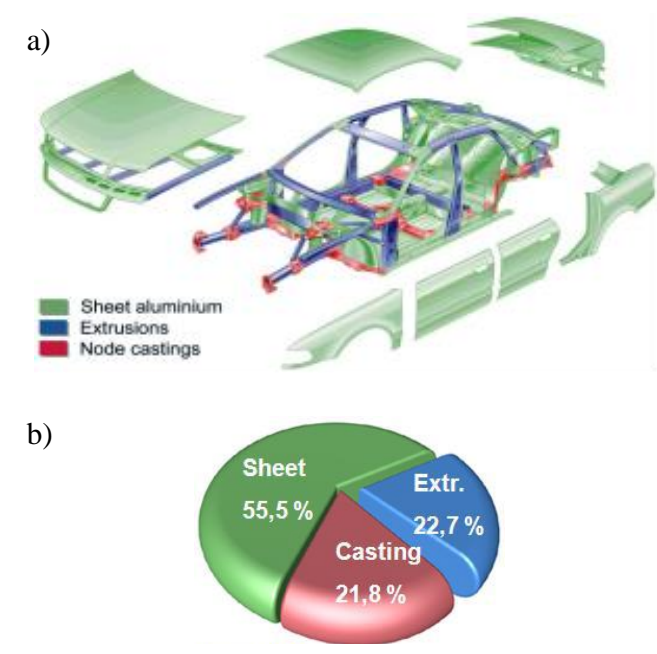

Fig. 1. Exploded view of Audi A8 space frame (a) and closures by weight (b)

However, a wide variety of aluminium alloys are available for a particular application. The selection of specific alloy by satisfying all the constraints without derailing the functional failure is always a major task. 
So far the manufacturers used Trial and error method which is not valid every time.

Multi Attribute Decision Making (MADM) methods are being more popular now a day to solve the critical situations of decision making in a systematic and logical way. These methods use simple mathematical formulae in complex decision making also. So far these methods are applied in many fields like Staff Selection [3], Alloy wheel material selection using magnesium alloys [4], Pharmacy product selection [5] and in many more [6].

Therefore, this paper exposes an organized approach for the selection of good material for automobile panels by the application of some MADM methods. Section 2 discuss the problem formulation while the section 3 and 4 describe the methodology and implementation of algorithms. Finally, conclusions are presented.

\section{PROBLEM STATEMENT}

As mentioned in the earlier section, the weight of an automobile can be reduced by replacing steel with an alternate material namely Aluminium.Cantor et al. [7] and Toroset al. [8] observed that depending on different regions and different manufacturing strategies wide range of aluminium alloys are applied in body panels. Based on features such as strength and formability, various alloys such as Heat treatable and non-heat treatable alloys are used in panels, developed from deep drawing process [9]. Further a survey is conducted on the available literature [10-13] w.r.t. Aluminium alloys and their necessary properties used in the automotive industry in view of panel applications. The researchers highlighted the prospects of various alloys that are being currently used as well as the research potentials of $\mathrm{Al}$ alloys in the near future. It is further observed that there are various alloys serving for the common application with each alloy is having its own merits and demerits. The alloys considered in the present study are tabulated in Table 1 .

The problem is modelled to select the best alloy among ten different materials satisfying seven criterions. This problem is complex as the second material posse's good thermal conductivity while the first material has good percentage of elongation. 6061 with T6 condition i.e. material 10 is a good choice in view of good ultimate tensile strength and hardness. The material for panel application must be the fittest of all.Therefore, the problem is modelled to identify and to select the best alloy among the compared with MADM methods The problem considered here is also a multi objective type as such it has to satisfy all the constraints and must produce a good quality solution.

\section{METHODOLOGY}

Multi Attribute Decision Making (MADM) methods or Multi Criterion Decision Making (MADM) methods are used when decision making is critical. These methods works with simple mathematical formulae and becoming more popular in the recent years in view of applications in vide fields. The generalised procedure of these MADM methods are depicted in Fig. 2.

There are a sub class of methods like SAW, WPM, AHP, TOPSIS, VIKOR, PROMETHEE, ELCTRE .etc under the common name MADM or MCDM. Among these SAW and WPM methods are simple and AHP and TOPSIS are more popular in view of high potentiality in various fields $[14,15]$.

Tab. 1. Decision Table for the selection of material

\begin{tabular}{ccccccccc}
\hline $\begin{array}{c}\text { S.N } \\
0\end{array}$ & Material & $\begin{array}{c}\text { Density } \\
\left(\mathrm{g} / \mathrm{cm}^{3}\right)\end{array}$ & $\begin{array}{c}\text { Thermal } \\
\text { conductivity } \\
(\mathrm{W} / \mathrm{mK})\end{array}$ & $\begin{array}{c}\text { Percentage } \\
\text { of } \\
\text { Elongation } \\
\text { at break }\end{array}$ & $\begin{array}{c}\text { Elasticm } \\
\text { odulus } \\
(\mathrm{GPa})\end{array}$ & $\begin{array}{c}\text { UTS } \\
(\mathrm{MPa})\end{array}$ & $\begin{array}{c}\text { YTS } \\
(\mathrm{MPa})\end{array}$ & $\begin{array}{c}\text { Hardnes } \\
\text { s } \\
(\mathrm{BHN})\end{array}$ \\
\hline 1 & AA6016-T4 & 2.7 & 190 & 27 & 69 & 200 & 110 & 55 \\
\hline 2 & AA6016-T6 & 2.7 & 210 & 11 & 69 & 280 & 210 & 80 \\
\hline 3 & AA5182-O & 2.65 & 130 & 12 & 68 & 280 & 130 & 69 \\
\hline 4 & AA5754-O & 2.67 & 130 & 19 & 68 & 210 & 90 & 52 \\
\hline 5 & AA5454-O & 2.69 & 130 & 17 & 69 & 240 & 100 & 61 \\
\hline 6 & AA5052 & 2.68 & 140 & 22 & 68 & 190 & 79 & 47 \\
\hline 7 & AA5454 & 2.69 & 130 & 17 & 69 & 240 & 100 & 61 \\
\hline 8 & AA5154 & 2.66 & 130 & 20 & 68 & 240 & 94 & 58 \\
\hline 9 & AA 6061-T4 & 2.7 & 170 & 18 & 69 & 230 & 130 & 63 \\
\hline 10 & AA6061-T6 & 2.7 & 170 & 10 & 69 & 310 & 270 & 93 \\
\hline
\end{tabular}




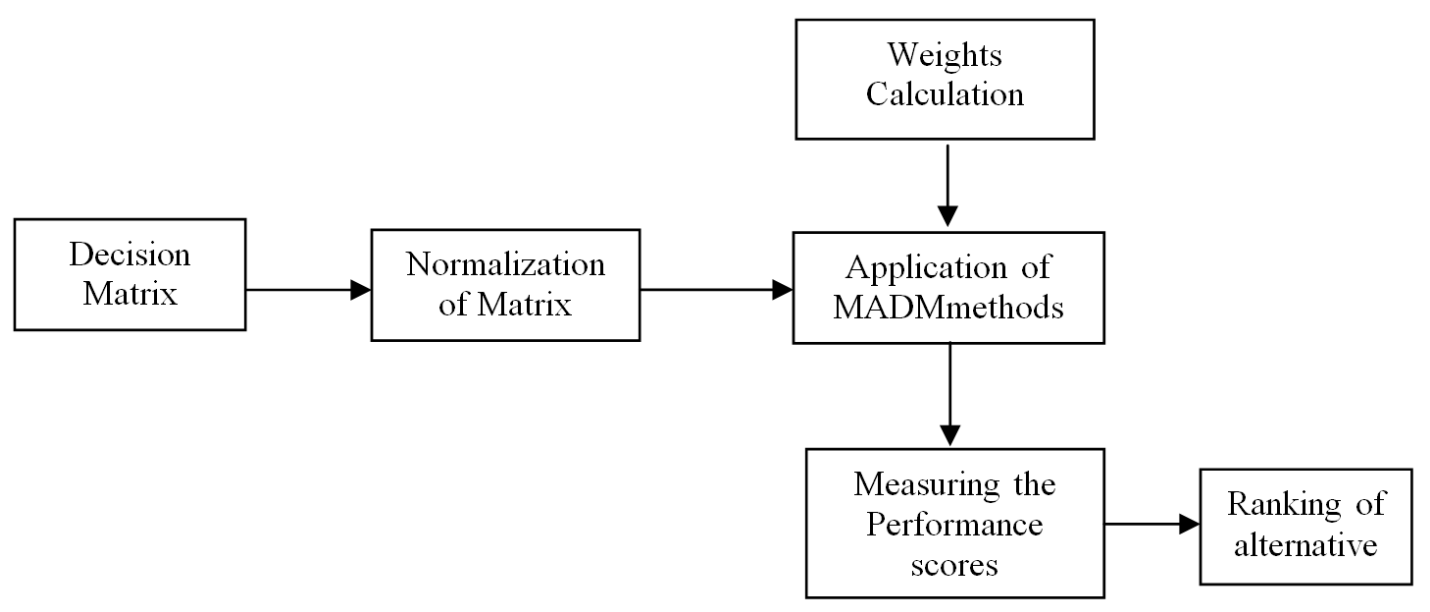

Fig. 2. Procedure involved in MADM Methods

\subsection{AHP method}

AHP Stands for Analytical Hierarchy Process developed by T.L Sathy in 1980. It is one of the most popular methods of MADM with many advantages. The major distinctive of the AHP method is to use pair-wise comparisons for comparing the alternatives with respect to the various criteria. It is easy to use and has lot of interdependence of parameters for better output. The ability of to handle large size problems is an another advantage of using this method $[15,16]$.

\subsection{TOPSIS Method}

Technique for Order of Preference by Similarity to Ideal Solution (TOPSIS) is another method under the category of MADM methods. In 1981, Ching-Lai Hwang and Yoon developed this method. This method is an approach to identify an alternative which is closest to the ideal solution and farthest to the negative ideal solution in a multi objective environment. After the weights calculation and normalization of data, identify the positive alternatives in and calculate the separation measures of each alternate. Then evaluate the relative closeness and rank. The detailed formulae and examples in calculating performance is widely available in web $[3,5]$. The advantage of this method is its ease in usage irrespective of problem size. TOPSIS has been successfully implemented in both Engineering, management and business and marketing domains [15].

\subsection{Entropy method}

Entropy method uses the decision table to compute the weights regardless operator's choice. Entropy methods have gain much importance in the recent years as these methods reduces the decision makers experiments as much as possible by implementing mathematical computation for determining the weights. A detailed procedure of entropy method is given by Farhad Hosseinzadeh Lotfi et al. [17]. In entropy method, the higher the difference in performance values is considered for more weight age and the materials with similar performance was given with lower weightage.

Tab. 2. Normalized data of decision Table 1

\begin{tabular}{lllllllll}
\hline S.No & Material & $\begin{array}{l}\text { Density } \\
\left(\mathrm{g} / \mathrm{cm}^{3}\right)\end{array}$ & $\begin{array}{l}\text { Thermal } \\
\text { conductivity } \\
(\mathrm{W} / \mathrm{mK})\end{array}$ & $\begin{array}{l}\text { Percentage of } \\
\text { Elongation at } \\
\text { break }\end{array}$ & $\begin{array}{l}\text { Elastic } \\
\text { modulus } \\
(\mathrm{GPa})\end{array}$ & $\begin{array}{l}\text { UTS } \\
(\mathrm{MPa})\end{array}$ & $\begin{array}{l}\text { YTS } \\
(\mathrm{MPa})\end{array}$ & $\begin{array}{l}\text { Hardness } \\
(\mathrm{BHN})\end{array}$ \\
\hline 1 & AA6016-T4 & 0.98148 & 0.90476 & 1.00000 & 1.00000 & 0.64516 & 0.40741 & 0.59140 \\
\hline 2 & AA6016-T6 & 0.98148 & 1.00000 & 0.40741 & 1.00000 & 0.90323 & 0.77778 & 0.86022 \\
\hline 3 & AA5182-O & 1.00000 & 0.61905 & 0.44444 & 0.98551 & 0.90323 & 0.48148 & 0.74194 \\
\hline 4 & AA5754-O & 0.99251 & 0.61905 & 0.70370 & 0.98551 & 0.67742 & 0.33333 & 0.55914 \\
\hline 6 & AA5454-O & 0.98513 & 0.61905 & 0.62963 & 1.00000 & 0.77419 & 0.37037 & 0.65591 \\
\hline 7 & AA5052 & 0.98881 & 0.66667 & 0.81481 & 0.98551 & 0.61290 & 0.29259 & 0.50538 \\
\hline 8 & AA5454 & 0.98513 & 0.61905 & 0.62963 & 1.00000 & 0.77419 & 0.37037 & 0.65591 \\
\hline 9 & AA5154 6061-T4 & 0.99624 & 0.61905 & 0.74074 & 0.98551 & 0.77419 & 0.34815 & 0.62366 \\
\hline 10 & AA6061-T6 & 0.98148 & 0.80952 & 0.37037 & 1.00000 & 1.00000 & 1.00000 & 1.00000 \\
\hline
\end{tabular}




\section{RESULTS AND DISCUSSIONS}

The implementation of MADM methods uses a sequence of steps as mentioned in Section 3. After the preparation of decision table (Table 1), the next step is preparing the Normalized Table based on beneficiary and non-beneficiary variables. MATLAB software is implemented to generate the data from the equations. Normalized matrix for the problem considered is shown in Table 2 .

The weights were computed according to Entropy method and are tabulated in Table 3 . From Table 3 , it can be observed that the large difference in YTS values of all the materials lead to higher weights while the weightage factors of density and Elastic modulus are very low. These values are corresponding to almost similar performance behavior of all materials in the decision table. It can also be understood that the selection of best material does not much influenced by these attributes.

\subsection{AHP method}

As per the procedure of AHP method, pair wise comparison of each alternate with other is prepared. Sample of pair wise matrices for alternatives 1, 10 are given in Table 4 (a) \& (b).

After obtaining the pairwise comparison matrices, the overall performance of alternatives i.e materials is obtained by multiplying the relative weight of each criterion with its consequent weight value of each alternative and summing over the characteristic for each alternative. The performance scores of each material obtained from AHP are shown in Fig. 3.

Tab. 3. Entropy Weights for the attributes

\begin{tabular}{ccccccc}
\hline $\begin{array}{c}\text { Density } \\
\left(\mathrm{g} / \mathrm{cm}^{3}\right)\end{array}$ & $\begin{array}{c}\text { Thermal } \\
\text { conductivity } \\
(\mathrm{W} / \mathrm{mK})\end{array}$ & $\begin{array}{c}\text { Percentage of } \\
\text { Elongation at } \\
\text { break }\end{array}$ & $\begin{array}{c}\text { Elastic modulus } \\
(\mathrm{GPa})\end{array}$ & $\begin{array}{c}\text { UTS } \\
(\mathrm{MPa})\end{array}$ & $\begin{array}{c}\text { YTS } \\
(\mathrm{MPa})\end{array}$ & $\begin{array}{c}\text { Hardness } \\
(\mathrm{BHN})\end{array}$ \\
\hline 0.000121 & 0.094519 & 0.241070 & 0.000146 & 0.063899 & 0.48693 & 0.113311 \\
\hline
\end{tabular}

Tab. 4. Pair Wise comparison matrices for each material

(a) Material 1

\begin{tabular}{|c|c|c|c|c|c|c|c|c|c|c|}
\hline & 1 & 2 & 3 & 4 & 5 & 6 & 7 & 8 & 9 & 10 \\
\hline 1 & 1.0000 & 1.0000 & 0.9818 & 0.9888 & 0.9963 & 0.9925 & 0.9963 & 0.9851 & 1.0000 & 1.0000 \\
\hline 2 & 1.0000 & 1.0000 & 0.9818 & 0.9888 & 0.9963 & 0.9925 & 0.9963 & 0.9851 & 1.0000 & 1.0000 \\
\hline 3 & 1.0188 & 1.0188 & 1.0000 & 1.0075 & 1.0150 & 1.0113 & 1.0150 & 1.0037 & 1.0188 & 1.0188 \\
\hline 4 & 1.0112 & 1.0112 & 0.9925 & 1.0000 & 1.0074 & 1.0037 & 1.0074 & 0.9962 & 1.0112 & 1.0112 \\
\hline 5 & 1.0037 & 1.0037 & 0.9851 & 0.9925 & 1.0000 & 0.9962 & 1.0000 & 0.9888 & 1.0037 & 1.0037 \\
\hline 6 & 1.0074 & 1.0074 & 0.9888 & 0.9962 & 1.0037 & 1.0000 & 1.0037 & 0.9925 & 1.0074 & 1.0074 \\
\hline 7 & 1.0037 & 1.0037 & 0.9854 & 0.9925 & 1.0000 & 0.9962 & 1.0000 & 0.9888 & 1.0037 & 1.0037 \\
\hline 8 & 1.0150 & 1.0150 & 0.9962 & 1.0037 & 1.0112 & 1.0075 & 1.0112 & 1.0000 & 1.0150 & 1.0150 \\
\hline 9 & 1.0000 & 1.0000 & 0.9814 & 0.9888 & 0.9963 & 0.9925 & 0.9963 & 0.9851 & 1.0000 & 1.0000 \\
\hline 10 & 1.0000 & 1.0000 & 0.9814 & 0.9888 & 0.9963 & 0.9925 & 0.9963 & 0.9851 & 1.0000 & 1.0000 \\
\hline
\end{tabular}

(b) Material 10

\begin{tabular}{|c|c|c|c|c|c|c|c|c|c|c|}
\hline & 1 & 2 & 3 & 4 & 5 & 6 & 7 & 8 & 9 & 10 \\
\hline 1 & 1.0000 & 0.6875 & 0.7971 & 1.0576 & 0.9016 & 1.1702 & 0.9016 & 0.9482 & 0.8730 & 0.5914 \\
\hline 2 & 1.4545 & 1.0000 & 1.1594 & 1.5384 & 1.3111 & 1.7021 & 1.3111 & 1.3793 & 1.2698 & 0.8602 \\
\hline 3 & 1.2545 & 0.8625 & 1.0000 & 1.3269 & 1.1311 & 1.4680 & 1.1311 & 1.1896 & 1.0952 & 0.7419 \\
\hline 4 & 0.9454 & 0.6500 & 0.7536 & 1.0000 & 0.8524 & 1.1063 & 0.8524 & 0.8966 & 0.8254 & 0.5591 \\
\hline 5 & 1.1090 & 0.7625 & 0.8840 & 1.1730 & 1.0000 & 1.2978 & 1.0000 & 1.0517 & 0.9682 & 0.6559 \\
\hline 6 & 0.8545 & 0.5875 & 0.6811 & 0.9038 & 0.7704 & 1.0000 & 0.7704 & 0.8103 & 0.7460 & 0.5053 \\
\hline 7 & 1.1090 & 0.7625 & 0.8840 & 1.1730 & 1.0000 & 1.2987 & 1.0000 & 1.0517 & 0.9682 & 0.6555 \\
\hline 8 & 1.0545 & 0.7250 & 0.8405 & 1.1153 & 0.9508 & 1.2340 & 0.9508 & 1.0000 & 0.9206 & 0.6236 \\
\hline 9 & 1.1454 & 0.7875 & 0.9130 & 1.2115 & 1.0327 & 1.3404 & 1.0327 & 1.0862 & 1.0000 & 0.6774 \\
\hline 10 & 1.6909 & 1.1625 & 1.3478 & 1.7884 & 1.5245 & 1.9787 & 1.5245 & 1.6034 & 1.4761 & 1.0000 \\
\hline
\end{tabular}




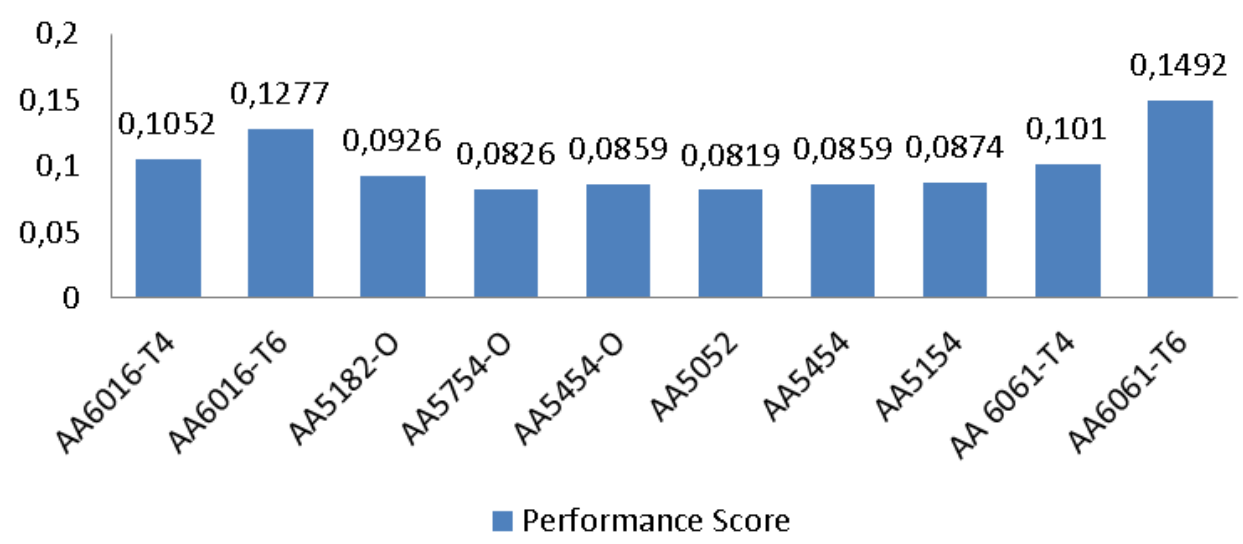

Fig. 3. Performance scores of each material according to AHP

It can be seen from Fig. 3.that the highest performance is score is for AA6061 - T6 material and the order of preference for the selection of materials according to AHP is $10-2-1-9-3-8$ - 7 - 5 - 4 - 6 .

\subsection{TOPSIS method}

With the normalized matrix and Weight matrix Normal Decision matrix $R_{i j}$ and Weighted Normalized matrix $V_{i j}$ are computed. From weighted normalized matrix , the ideal best and worst solutions $\left(V^{+}, V^{-}\right)$as well as the separation measures $\left(S^{+}, S\right)$ for each alternate is calculated with the TOPSIS formulae are shown below in Table 5 and 6 .

Tab. 5. Ideal Best and Ideal Worst Solutions $\left(\mathrm{V}^{+}, \mathrm{V}^{-}\right)$

\begin{tabular}{lll}
\hline Attributes & $\mathrm{V}^{+}$ & $\mathrm{V}^{-}$ \\
\hline 1 & 0.00003 & 0.00003 \\
\hline 2 & 0.04034 & 0.02497 \\
\hline 3 & 0.11433 & 0.04234 \\
\hline 4 & 0.00004 & 0.00004 \\
\hline 5 & 0.02599 & 0.01568 \\
\hline 6 & 0.28961 & 0.08473 \\
\hline 7 & 0.05110 & 0.02582 \\
\hline
\end{tabular}

Tab. 6. Separation measures of materials $\left(\mathrm{S}^{+}, \mathrm{S}^{-}\right)$

\begin{tabular}{lll}
\hline Materials & $\mathrm{S}^{+}$ & $\mathrm{S}^{-}$ \\
\hline 1 & 0.1731 & 0.0802 \\
\hline 2 & 0.0937 & 0.1427 \\
\hline 3 & 0.1643 & 0.0571 \\
\hline 4 & 0.1980 & 0.0400 \\
\hline 5 & 0.1887 & 0.0382 \\
\hline 6 & 0.2081 & 0.0508 \\
\hline 7 & 0.1887 & 0.0382 \\
\hline 8 & 0.1927 & 0.0458 \\
\hline 9 & 0.1561 & 0.0654 \\
\hline 10 & 0.0723 & 0.2068 \\
\hline
\end{tabular}

By using the data of Table 6. The performance scores of each material is calculated and is shown in Fig. 4.

As seen from Fig. 4, AA 6061 - T6 has the highest performance score than the other materials and the order of preference for the selection of materials in panel application according to TOPSIS is $10-2-1-9$ $-3-6-8-7-5-4$.

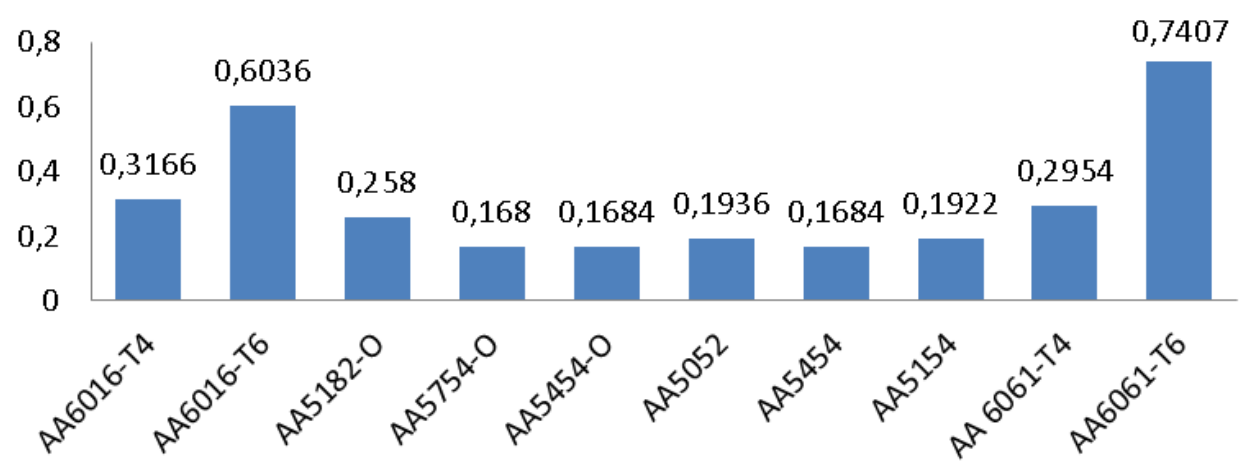

Performance Score

Fig. 4. Performance scores of each material according to TOPSIS 


\subsection{Comparison of both methods}

Based on the performance scores obtained from AHP and TOPSIS, Ranking was given to each material and Tabulated in Table 7.

Tab. 7. Ranking of Materials

\begin{tabular}{llll}
\hline S.No & Material & $\begin{array}{l}\text { AHP } \\
\text { RANK }\end{array}$ & $\begin{array}{l}\text { TOPSIS } \\
\text { RANK }\end{array}$ \\
\hline 1 & AA6016-T4 & 3 & 3 \\
\hline 2 & AA6016-T6 & 2 & 2 \\
\hline 3 & AA5182-O & 5 & 5 \\
\hline 4 & AA5754-O & 9 & 10 \\
\hline 5 & AA5454-O & 8 & 9 \\
\hline 6 & AA5052 & 10 & 6 \\
\hline 7 & AA5454 & 7 & 8 \\
\hline 9 & AA5154 & 6 & 7 \\
\hline 10 & AA 6061-T4 & 4 & 4 \\
\hline
\end{tabular}

It can be observed that, the ranking of materials is not uniform as each method has its own procedure to rank the alternates. However, for this particular problem both methods suggested AA 6061-T6 is the best choice of material. So the usage of AA 6061 - T6 material will enhance the performance of automobile panel as suggested by MADM methods.

\section{CONCLUSIONS}

In view of weight reduction strategies in automotive industry, the replacement of steel with aluminium is found to be the best option. As there are number of Aluminium alloys for the same purpose and to replace with the suitable alloy satisfying the functional requirement is a challenging task. Ten different alloys with seven attributes are considered in the present study. The procedure involved for the selection panel applications by the class of MADM methods like AHP and TOPSIS is given in detail and are successfully implemented. Entropy method was adopted to find the weights and are incorporated to find the solution quality. From the results, it is observed that the material AA6061 with T6 condition is the best alternate. Though the two methods AHP and TOPSIS differ in the respective procedures but for this particular problem the both methods suggested the same material as the best choice. The present approach tries to find the best material in a logical way, still further research should be carried out for practical application of the proposed material in the respective field.

\section{Acknowledgment}

This work is carried out as a part of UGC-MRP [MRP-6754/16 (SERO/UGC)]. On this occastion, I would like to thank the University Grant Commission, India.

\section{Nomenclature}

The following Nomenclature is used in the present study

\begin{tabular}{|c|c|c|}
\hline \multicolumn{3}{|c|}{ Symbols } \\
\hline$V^{+}, V$ & - & Ideal Best and Worst Solutions \\
\hline$S^{+}, S^{-}$ & - & Separation Measures \\
\hline T4 & - & Solution heat treated with natural aging \\
\hline T6 & - & Solution heat treated with Artificial aging \\
\hline$O$ & - & Annealed \\
\hline
\end{tabular}

Acronyms

MADM - Multi Attribute Decision Making

AHP - Analytical Hierarchy Process

TOPSIS - $\quad$ Technique for Order of Preference by

Similarity to Ideal Solution

SAW - $\quad$ Simple Additive Method

WPM - Weighted Product Method

VIKOR - $\quad$ Vlse Kriterijumska Optimizacija

Kompromisno Resenje

PROMETHEE - Preference ranking organization method for enrichment evaluation

$\begin{array}{lll}\text { ELECTRE } & -\quad \begin{array}{l}\text { ELimination and Choice Expressing } \\ \text { REality }\end{array} \\ \text { BHN } & - & \text { Brinell Hardness Number } \\ \text { UTS } & - & \text { Ultimate Tensile Strength } \\ \text { YTS } & - & \text { Yield Tensile Strength } \\ \text { AA } & - & \text { Aluminium Alloy }\end{array}$

\section{References}

1. Ungureanu, C.A., Das, S., Jawahir, I.S. (2007). Lifecycle Cost Analysis: Aluminum versus Steel in Passenger Cars. TMS (The Minerals, Metals and Materials Society), pp:11-24.

2. Naka, T., Torikai, G., Hino, R., Yoshida, F.( 2001). The effects of temperature and forming speed on the forming limit diagram for type 5083 aluminum-magnesium alloy sheet. J. Mater. Process. Technol. 113,pp: 648-653.

3. D.Sameer Kumar, S. Radhika , K.N.S. Suman. (2013), MADM Methods for Finding The Right Personnel in Academic Institutions", International Journal of $u$ - and e-Service, Science and Technology, Vol.6, No.5 pp.133144. http://dx.doi.org/10.14257/ijunesst.2013.6.5.12

4. D.SameerKumar, K.N.S. Suman, (2014) Selection of Magnesium Alloy by MADM Methods for Automobile Wheels", International Journal of Engineering and Manufacturing, 2 , pp: 31-41. http://dx.doi.org/10.5815 /ijem.2014.02.03

5. FarzanaElahi et al. (2017), Pharmaceutical Product Selection: Application of AHP, International Journal of Business and Management; Vol. 12, No. 8 , pp: 193-200.

6. R. Venkata Rao , (2007), Decision Making in the Manufacturing Environment using Graph Theory and Fuzzy Multiple attribute Decision Making Methods ,Springer - Verlag London Limited.

7. Cantor B, Grant P, Johnston C (2008). Automotive engineering: lightweight, functional, and novel materials. CRC Press.

8. Toros S, Ozturk F, Kacar I (2008). Review of warm forming of aluminum- magnesium alloys. J. Mater. Process. Technol. 207 , pp: 1-12.

9. D Swapna, Srinivasa Rao Ch, S Radhika , (2018), A Review on Deep Drawing Process, International Journal of Emerging Research in Management and Technology, Vol 6, Issue 6, pp 146-149. 
10. W.S. Miller, L. Zhuang, J. Bottema, A.J. Wittebrood, P. De Smet , A. Haszler, A. Vieregg, (2000), Recent development in aluminium alloys for the automotive industry", Materials Science and Engineering , A280, pp: $37-49$.

11. C-H. Ng, S. N. M. Yahaya and A. A. A. Majid, (2017), Reviews on aluminum alloy series and its applications", Academia Journal of Scientific Research vol 5 Issue 12, pp: 708-716.

12. Savkin Alexey Nikolaevich, Andronik Artem Valerievich, Gorunov Andrey Igorevich, Sedov Alexander Alexandrovich, Sukhanov Mikhail Alexandrovich, (2014) Advanced materials of automobile bodies in volume production, European Transport $\backslash$ Trasporti Europei, Issue 56, Paper $\mathrm{n}^{\circ} 10$, ISSN 1825-3997.

13. Takeo SAKURAI, (2008), The Latest Trends in Aluminum Alloy Sheets for Automotive Body Panels, Material \& Process Research Section, Aluminum Sheets \& Coils Department Moka Plant, Aluminum \& Copper Company, KOBELCO TECHNOLOGY REVIEW NO. 28.

14. Jureen Thor et al. (2013), Comparison of Multi Criteria Decision Making Methods From The Maintenance Alternative Selection Perspective, The International Journal Of Engineering And Science (IJES), Volume2, Issue6, Pp 27-34.

15. Velasquez and Hester (2013), An Analysis of MultiCriteria Decision Making Methods, International Journal of Operations Research [IJOR ] , Vol. 10, No. 2, pp: 56-66.

16. Saaty, T.L., (1980). The Analytic Hierarchy Process, McGraw-Hill, New York

17. Farhad Hosseinzadeh Lotfi and Reza Fallahnejad (2010), Imprecise Shannon's Entropy and Multi Attribute Decision Making, Entropy , 12, pp : 53-62. doi:10.3390/e12010053.

\section{Biographical notes}

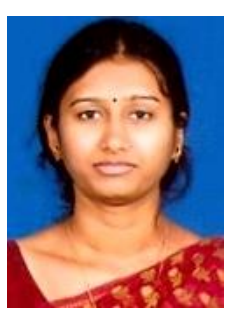

D. Swapna received her M.Tech Degree in 2007 with specialization in $\mathrm{CAD} / \mathrm{CAM}$. She is currently preparing the research on Development of Alumium panels for automitove applications with the funding of University Grants Commission (UGC), New Delhi, India.

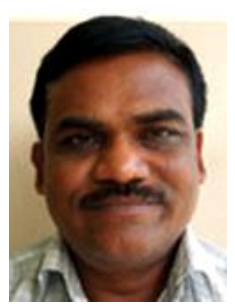

Ch. Srinivasa Rao is a professor in Mechanical Engineering Department of Andhra University College of Engineering, Visakhapatnam. He guided more than 8 research scholars and several Post Graduate students in various domains of Mechanical Engineering. He published more than 150 national and International journals with high eminence.

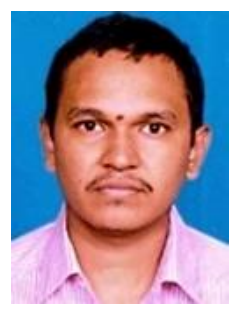

D. Sameer Kumar working as assistant professor in the Department of Mechanical Engineering, R.V.R. \& J.C. College of Engineering, Guntur. His areas of interest include Material selection using MADM methods as well as Design and Development of composites applied to automotive industry.

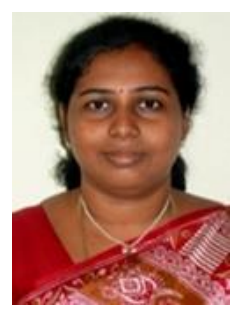

S. Radhika received her Ph.D. from Andhra University in 2015. She is currently associate professor in the Department of Mechanical Engineering, R.V.R. \& J.C. College of Engineering, Guntur. Her areas of interest is to work with Optimization principles applied to manufacturing strategies. 
